\title{
乳突炎様症状で発症した腫瘤形成性骨髄性白血病例
}

\author{
神谷恵理子 - 竹内 英二* · 北野 博也* \\ 櫻井 弘徳・鈴木 幹男 - 矢沢代四郎
}

\section{A Case of Granulocytic Sarcoma (Chloroma) with Acute Mastoiditis}

\author{
Eriko Kamiya, Hironori Sakurai, Mikio Suzuki and Yoshiro Yazawa \\ (Shiga University of Medical Science)
}

Eiji Takeuchi and Hiroya Kitano

(Tottori University School of Medicine)

\begin{abstract}
We report a case of Granulocytic Sarcoma (chloroma) with acute mastoiditis in a 14-year-old male. The patient was brought to our clinic because of left facial nerve palsy and acute bilateral otitis media. He was diagnosed as having acute mastoiditis, and underwent left mastoidectomy. One week later, however, leukocyts increased and the wound did not heal. A mass lesion in the mastoid was detected on MRI. We biopsied the mastoid and found Granulocytic Sarcoma (chloroma). Thereafter, the patient underwent chemo- and radiation therapy, but died due to the general deterioration of his condition. In this case, pathological examination and MRI were useful for establishing the final diagnosis.
\end{abstract}

Key words : granulocytic sarcoma, mastoiditis, leukemia, MRI

はじめに

腫瘤形成性の急性骨髄性白血病は緑色腫（chloroma） とも呼ばれ，その腫瘤は骨・骨髄・縱隔・皮膚・乳房な ぞに発生する ${ }^{1)}$ ，今回われわれは，急性乳突炎様症状を 呈して発症し, 診断に難渋した腫瘤形成性の急性骨髄性 白血病の 1 症例を経験したので報告する.

\section{症例}

症例：14 歳, 男児.

主訴：左耳漏, 左顔面神経麻痺.

家族歴・既往歴：特記すべきことなし.

現病歴: 平成 13 年 6 月初旬より左耳痛を認めるも放置 していた. 7月初旬, 近医にて外耳炎の診断のもと抗生 物質等の内服を開始され, 耳痛は軽減したが持続してい
た. 7 月 8 日に左顔面神経麻痺が出現し, 9 日に急性乳突 炎の疑いにて当科紹介受診となった。

局所所見 : 左外耳道の腫脹, 左耳漏が著明で鼓膜は観 察できなかった. 耳介後部の腫脹および左顔面神経麻痺 を認めた（図1).

検查所見: 血液検查で白血球 $7200 / \mu 1, C R P ~ 1.2 \mathrm{mg} / \mathrm{dl}$, 体温 $37.8^{\circ} \mathrm{C}$ と軽度の炎症所見を認めた以外異常はな かった. 顔面神経スコアは 40 点法で 4 点, 聴力は左混合 性難聴を示した。 CT では, 左乳突蜂巣の発育は良好で あるが含気はほとんど認めず，乳突洞・顔面神経管・外 耳道等の骨破壊像は認められなかった（図 2)。耳漏に対 する細菌検查では黄色ブドウ球菌（MSSA）が検出され た.

経過(1):急性乳突炎とそれに伴う顔面神経麻痺と考元， 


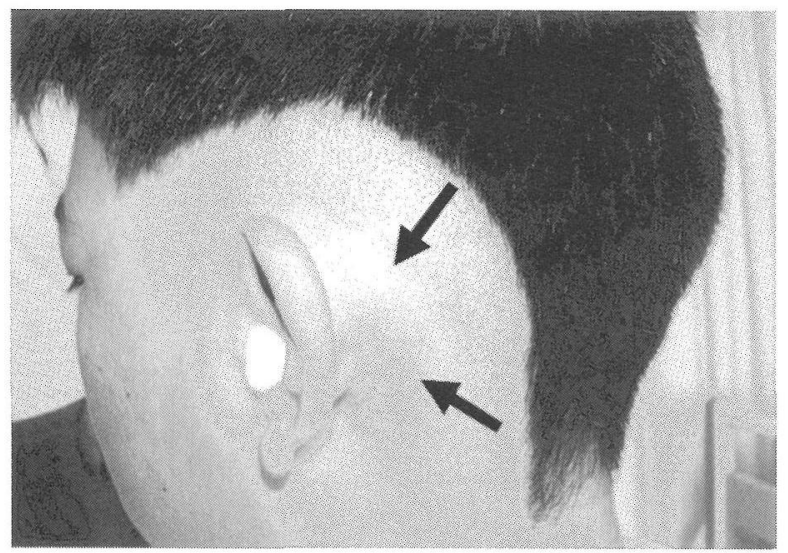

図 1 術前局所所見（左後方）

耳介後部の腫脹を認める（矢印）。

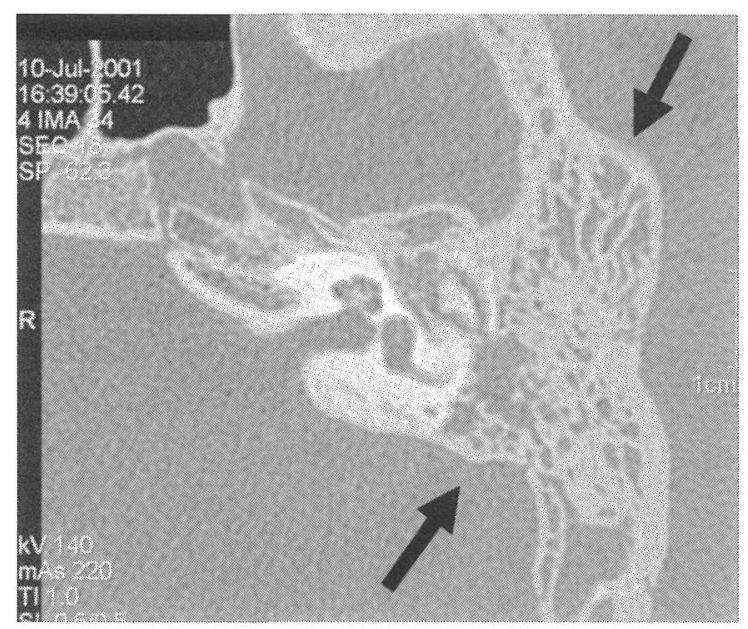

図 2 CT 所見 (単純)

矢印は隔壁が保たれている乳突蜂栄を示す。

7 月 9 日に即日入院の上，抗生物質投与と顔面神経麻痺 に対するステロイド投与を開始した。症状不変のため, 感染源除去目的にて7月 12 日全身麻酔下に左乳突削開術 を施行した。

手術所見 (1): 乳突洞内は肉芽組織で充満しており，膿 は少量であった。

病理組織学的所見：手術的に採取した乳突洞内組織の 病理組織学的所見では，肉芽組織と好酸球およびリンパ 球等の浸潤がみられるのみであった（図 3)。

経過(2)：術後 7 月 16 日に CRP は正常值となり，発熱 も認めず，顔面神経麻痺は改善傾向が認められた $(10 / 40$ 点)。特に異常所見を認めず経過していたが，7月23日

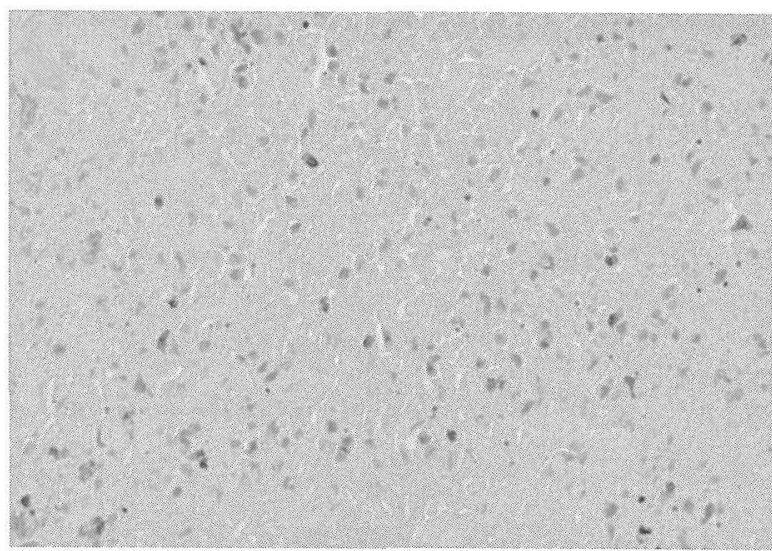

図 3 病理組織学的所見 (HE 染色, $\times 100)$

肉芽組織のなかに好酸球, リンパ球等炎症細胞の浸潤を 認める。

頃より左頸部の軽度腫脹と創部の治癒遷延を認め，血液 検查では白血球 $13,000 / \mu \mathrm{l}, \mathrm{CRP} 0.6 \mathrm{mg} / \mathrm{dl}$ と炎症反応が 再上昇した。 7 月 26 日, 頸部超音波検査にて左リンパ節 腫脹を認め, 精查のために頭部と頸部の MRI を施行し た。左側頭骨を中心に耳下腺部にかけて T1 強調画像で はやや高信号，T2 ではやや低信号，T1 Gd 造影強調画像 で著明に増強される辺縁不明瞭な病変が認められ，冠状 断では頭蓋内の硬膜に治って側頭葉から小脳にかけて広 範囲に広がる病変が認められた（図 4).MRI 所見と頸部 の腫脹や創部の治癒が遷延していることなどから腫瘍の 可能性や粘稠度の高い硬膜下膿瘍を考慮し，7月28日全 身麻酔下にて頸部リンパ節生検と，生検を兼ねた再度の 乳突削開術を行った。

手術所見(2)：創部を開放したところ, 膿汁の流出は認 められず肉芽組織があるのみで，肉芽組織が乳突洞から 頭蓋内へ広がっていったと思われる中頭蓋窩および後頭 盍窩の骨欠損部を認めた（図 5)。

経過(3) : 乳突洞内の骨欠損部から採取した肉芽組織の 病理組織検査では，核が不整形に腫大した腫瘍細胞がび まん性に組織間隙をつたって増殖しており，胞体に好酸 性顆粒を持つ異形細胞も散見され，悪性リンパ腫が疑わ れた。当院小览科に転科の上，骨髄穿刺等精密検査を施 行すると, 腫瘤形成性の急性骨髄性白血病と診断され(図 6）化学療法が施行された。肾科転科後の精査で同様の 腫瘤が腹腔内にも認められたが，化学療法施行後約 1 力 月で腫瘤は縮小し，血液中の骨髄芽球も消失した。

1 回目の手術時に採取した標本で，後に免疫染色にて 

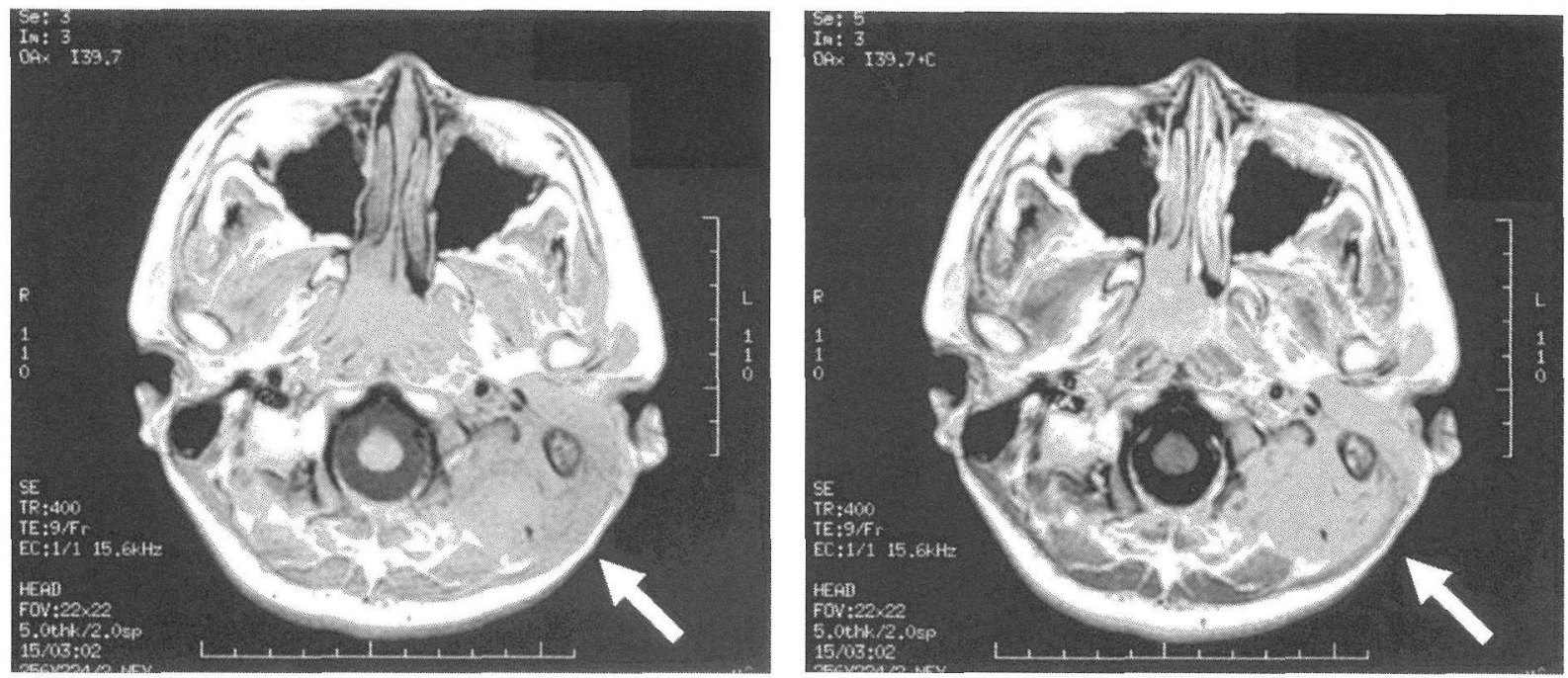

図 4 MRI 所見（左：T1 強調画像, 右： T1Gd 造影強調画像）

左側頭骨を中心に耳下腺部にかけて造影にて著明に増強される病変を認める（矢印）。
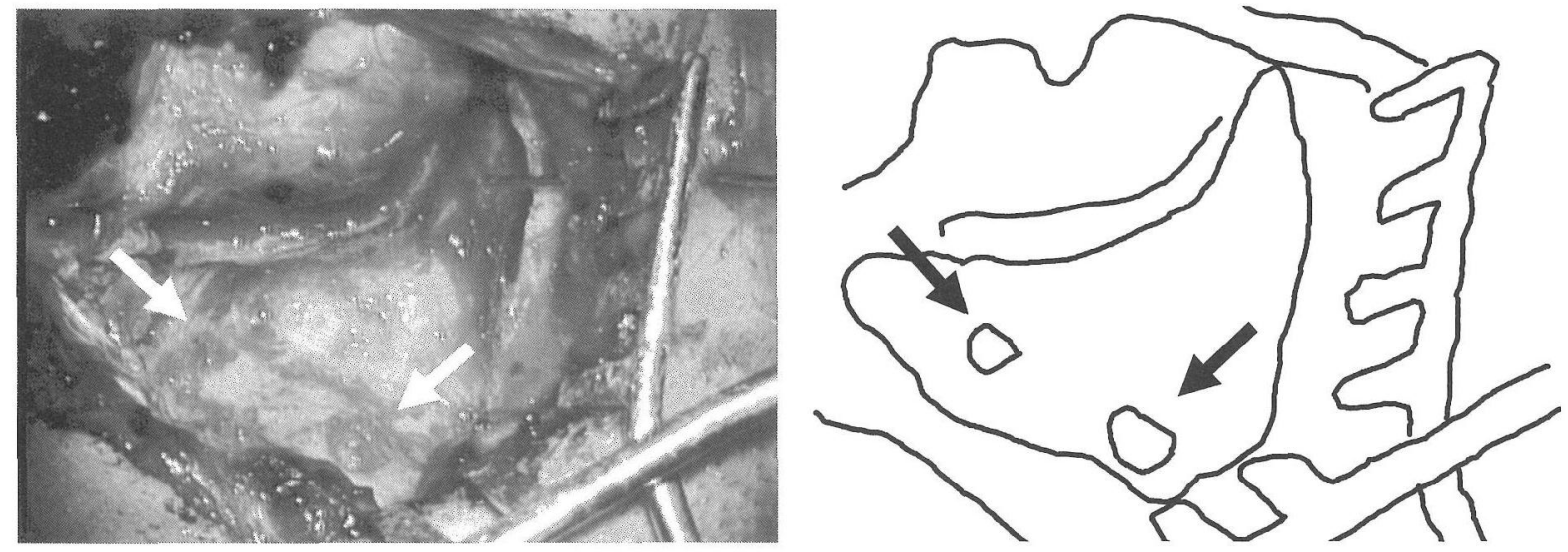

図 5 術中所見

肉芽組織の広がりを認める。矢印は骨融解により頭蓋内一浸潤したルートを示す。

精查したところ未熟な骨髄芽球が認められた（図 7)。さ らに 2 回目の手術当日の血液検查にても骨䯣芽球吕検出 された。

その後しばらくは経過良好であったが，腹腔内に再発 腫瘤を認めたため化学療法や放射線治療で経過観察し, 再発寛解を繰り返していた。しかし，治療効果が得られ ず状態悪化で平成 15 年 2 月に死亡した。

\section{考察}

腫瘤形成性骨髄性白血病は, 緑色腫（chloroma）や顆 粒球肉腫（granulocytic sarcoma）ともいわれ，骨髄細胞 由来の腫瘤形成性腫瘍と定義される。組織学的には構造 細胞が白血病性骨髄芽球や一部成熟した顆粒球系細胞 からなる21。緑色腫とは King3) によって 1853 年に唱えら れ，腫瘤が空気に触れると緑色を呈することからこの名 が付けられた。

診断は, 細胞組織学的所見と免疫組織学的所見による ことが多い，免疫染色においては，顆粒球系細胞に特徽 的であるペルオキシダーゼや好中球系細胞に特異的であ るクロロアセテートエステラーゼが陽性であることや， 


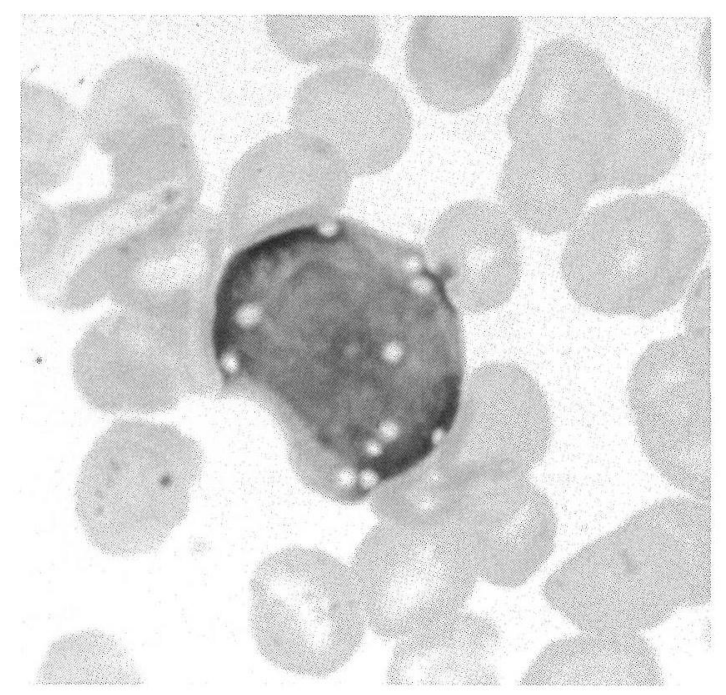

図 6 病理組織学的所見（免疫染色，×400） 髄液中に白血病細胞の浸潤を認める.

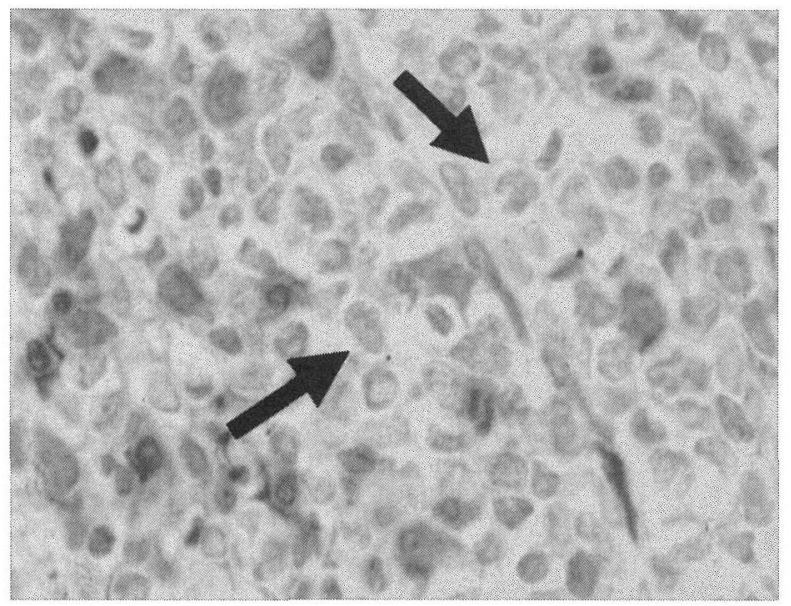

図 7 病理組織学的所見（免疫染色， × 400） 免疫染色にて未熟な骨髄芽球を認める.

顆粒球系表面マーカーが陽性であることなど骨髄系由来 の細胞を確認した上で確定診断が得られる4)。また，白 血病像を呈する末梢血像や骨髄所見む重要な診断材料で ある。乳突削開などによる生検にて確定診断が得られる ことも多いが5) 9)，より侵襲の少ない方法として鼓室 内貯留液による細胞診も有用であるとの報告むある ${ }^{10)}$. 今回の症例では, 乳突洞内腫瘤の免疫染色で, 骨髄系由 来の細胞に陽性である MAC387 にて陽性，また髄液中に む,ペルオキシダーゼ陽性である腫瘍細胞が認められた。
死後に採取された側頭骨病理組織学的所見では, 中耳・ 内耳ともに白血病細胞の浸潤と出血が認められており, また浸潤の形式として螖牛神経および前庭神経に沿って 内耳の外リンパ腔に達したり骨膜から直接ハーヴァース 管を経て骨膜に達して限局性増殖もきたしたものが大半 であると報告されている11) 13).

腫瘤は種々の臓器に発生する可能性があり,特に縱隔・ 皮膚・骨・リンパ節に多く122144，骨のなかでは，脊椎骨， 胁骨, 胸骨, 頭蓋, 大腿骨に多いとされる ${ }^{14)}$ 。この腫瘤 による局所病変が白血病の初期症状を出現させることも あり，その時点で末梢血に異常のないことも多いが，半 数以上の患者は数カ月以内で急性骨髄性白血病を発症す るとされる，また，腫瘤形成の時期によって臨床的経過 から 3 型に分類されている2). 1 型は臨床的に白血病が認 められない症例に本症がみられ，急性骨髅性白血病の前 兆と考元られる場合。2 型は慢性骨髄性白血病や他の骨 䯣増殖性疾患に伴う場合. 3 型は急性骨髄性白血病に合 併している場合で，剖検時に発見されることも多い，自 験例は 1 型であり，このパターンは他の全身的な症状が ないために見逃されやすく，手遅れとなることも少なく な( ${ }^{815) \sim 17) . ~}$

白血病患者が耳症状を呈する頻度は少なくない。野々 村ら ${ }^{18)}$ は, 白血病の経過中には $20 \%$ 前後の頻度で耳症状 が出現し，白血病と診断される前に耳症状を呈するもの が 5 〜 10\%あるものと考光られると述べている. Druss ${ }^{19}$ によると 148 人の白血病患者のうち 25 人 $(16.9 \%)$ に耳 症状を呈したとしており，その症状としては，難聴・耳 鳴・眩量・耳痛・耳漏・耳閉感挍よび顔面神経麻痺とし ている．自験例でも同様に，耳漏と顔面神経麻㾇をきた しており, 白血病の前駆症状であったと思われる。

これらの発症する機序としては, 白血病細胞の神経や 骨への浸潤, 出血傾向による内耳中中耳の出血, さらに 顆粒球減少・未熟白血球增加・化学療法などによる免疫 不全による感染が考えられる(4)6161618)20) 22).

鑑別疾患としては悪性リンパ腫があり, 病理学者に とっても診断が困難であることが多いとされている2). 自験例でも1回目の生検では炎症性細胞のみと診断され， 2 回目も当初は悪性リンパ腫の疑いが強かったが，免疫 染色にて骨髄性白血病と診断された。

CT P MRI 等の画像診断においてはこの疾患に特有 のものはなく，一般に充実性の腫瘤像や肉芽・浸出液 と同様の強調像を呈する。CTにおいては骨破壊を認め 
ず，乳突蜂巣の隔壁もよく保たれている場合が多 (4) 6)9910)20233. Almadori ら 24) は感染と腫煌の違いを対 比でき簡便さも考慮して，CTが有用であると述べてい るが，自験例ではより詳しい軟部組織像が得られたとい う点で MRI が有用であった。

治療については, 急性骨髄性白血病の初発症例と同様 に化学療法による寛解導入療法が行われる. 近年放射線 治療が非常に有効との報告があり，化学療法にて完全宽 解が得られた後, 局所に対しては放射線治療を追加する ことが多い 10221)。自験例でも初めに化学療法を施行し寛 解が得られ, 腹腔内腫瘤に対しては放射線治療を追加し た.

予後については一般に不良であり, 熊谷ら ${ }^{4)}$ は, 本疾 患の $44 \%$ が 5 カ月から 2 年以内に急性転化すると報告し ている.

今回の症例において，われわれはまず急性乳突炎と診 断した。通常の急性乳突炎の経過では, 主に急性中耳炎 に伴う耳痛・耳漏・発熱から始まり，炎症が進むにつれ て耳介後部や外耳道後壁の発赤・腫脹がみられ, さらに 重症化すると顔面神経麻痺や髄膜炎, 脳膿瘍を呈するこ ともある. 画像所見では, 乳突洞・乳突蜂巣全体にびま 乙性炎症性院影を認め, 蜂巣の隔壁は融解・消失する2). これらと比較して自験例の経過を一見すると通常の乳突 炎と同様の所見であるが，異なる点として CT にて骨破 壞を認めなかったこと，MRIにて T1で高信号，T2で低 信号であり通常の膿瘍ではなく, 腫瘤性病変の所見を呈 していたことが挙げられる。 また術中所見においては, 急性症状を呈しているにもかかわらず，乳突洞内に膿汁 があまり認められずに肉芽形成が著明であったことが挙 げられる，身体所見においては，耳介後部の腫脹が触診 上やや硬であったこと, 創部の治癒遷延がみられたこと, 頸部の腫脹がみられたことなどが挙げられる。 今回の症 例においては，悪性腫瘍疾患も念頭におき，リンパ腫や 白血病などの血液疾患も考慮した免疫染色も含めた病理 検査をすすめるなどの適切な精査が早期より必要であっ たと思われる。

\section{まとめ}

急性乳突炎様症状を呈して発症した腫瘤形成性骨髄性 白血病の 1 症例を報告した.

抗生剂投与に不応の重症乳突炎や，CT 等画像所見で 乳突蜂巣の隔壁が保たれ，全身的炎症所見に反して，乳
突洞内に膿瘍形成よりも肉芽形成が著明な例などの通常 とやや異なるような所見や経過を呈している乳突炎にお いては，本疾患の可能性も考慮し，MRI や免疫組織も含 めた病理組織検査を施行して適切な診断が必要となるこ とを痛感した。

\section{参考文献}

1）長尾忠美，上村致信，土岐博信，他：腫瘤形成性白血病の 治療に関する臨床的研究. 臨床血液 $16: 19 \sim 24,1975$.

2) 内田立身, 西原利男: 骨髄芽細胞腫 (緑色腫)。別冊日本臨 床 領域別症候群 $22: 180 \sim 182 ， 1998$.

3) King A : A case of chloroma. Mon J Med $17: 97,1853$.

4）熊谷正樹, 桜田隆司, 营原知広, 他：頸部腫瘤を主訴とし た顆粒球肉腫の 1 症例. 耳喉頭頸 $68: 501 \sim 504 ， 1996$.

5）吉原重光, 行木英生 : 側頭骨蜂巣に浸潤を示した急性骨髄 性白血病の 1 例. 臨床耳科 $15: 202 ， 1988$.

6) 工藤裕弘, 深谷 卓 : 急性骨髄性白血病の完全寛解期に顔 面神経麻痺・内耳障害を呈した一症例. 臨床耳科 $13: 488$ $\sim 489,1986$.

7) Thompson DH, Ross DG and Reid JW : Granulocytic sarcoma (chloroma) initially seen as acute mastoiditis. Arch Otolaryngol $108: 388 \sim 391,1982$.

8) Chapman P and Johnson SA : Mastoid chloroma as relapse in acute myeloid leukaemia. J Laryngol Otol $94: 1423 \sim 1427$, 1980.

9）加藤洋子, 飯野ゆき子, 鳥山 稔 : 難聴と顔面神経麻痺を 来した急性骨髄性白血病症例。臨床耳科 $16: 190,1989$.

10）間口四郎，田淵伴秀，熊谷雅彦，他：白血病の側頭骨浸潤 一鼓室内貯留液細胞診の有用性一. 日耳鼻 93:1320～1327, 1990.

11）斉藤龍介, 井口郁雄, 末広倫雄, 他 : 顔面神経麻痺と難聴 を呈した白血病症例の側頭骨病理所見. 臨床耳科 $14: 384$ $\sim 385,1987$.

12）野村恭也, 平出文久 : 乳様突起炎 - 迷路炎 - 顔面神経麻痺 を併発した急性骨髄性白血病例. 耳鼻 21:584〜588, 1975.

13）小島 瑞：腫瘤形成性白血病. 日本血液学会雑誌 $26: 62 \sim$ 68, 1963.

14）栗田宗次：腫瘤形成性白血病について。臨床血液 $23: 433$ $\sim 440,1982$.

15）竹山 勇，小津雷助，磯貝 豊，他：急性中耳炎および顔 面神経麻痺を初発症状とした急性骨髄性白血病の 1 例。耳 喉 $45: 413 \sim 421,1973$.

16）大蔵眞一，加我君孝 : 難聴を呈した白血病 4 症例の側頭骨 病理. Audiology Japan 34:104 109, 1991.

17）奥 常幸，斉藤政隆，新関泰夫，他：顔面神経麻痺を初発 症状とした急性骨髄性白血病の 1 例. 臨床耳科 $13: 486$ 〜 487, 1986. 
18）野々村直文, 大竹欣哉: 耳症状を呈した白血病の 2 症例. 耳鼻臨床 $77: 779 \sim 784,1984$.

19) Druss JG : Aural manifestations of leukemia. Arch Otolaryngol $42: 267 \sim 274,1945$.

20）堀江 貴, 中島香代子：耳科学的症状を観察した急性骨髄 性白血病（AML）の 2 例. 臨床耳科 13:484 485, 1986 .

21）西野 宏, 平出文久, 森田 守: 放射線照射が奏功した急 性骨髄性白血病の側頭骨浸潤症例. 臨床耳科 15:203, 1988 .

22）藤波 彰, 中西康詞, 阪田まり子, 他：治療中止 5 年後に 突発性難聴を発症した急性骨髄性白血病. 小児内科 $26: 119$ $\sim 122,1994$.
23）飯田祐起子, 工藤葉子, 杉尾雄一郎, 他：耳科的諸症状を 呈した急性骨髄性白血病例. 耳鼻臨床 91:477〜 482, 1998.

24) Almadori G, Del Ninno M, Cadoni G, et al. : Facial nerve paralysis in acute otomastoiditis as presenting symptom of FAB M2, T8; 21 leukemic relapse: case report and review of the literature. Int J Pediatr Otorhinolaryngol $36: 45 \sim 52,1996$.

原稿受付 : 平成16年 4 月 21 日

原稿採択 : 平成16年 7 月 14 日

別刷請求先 : 神谷恵理子

于522-8539 滋賀県彦根市八坂町 1882

彦根市立病院耳鼻咽喉科 